\title{
PENGARUH JARAK TANAM DAN PEMBERIAN DOSIS PUPUK KANDANG TERHADAP PERTUMBUHAN DAN HASIL TANAMAN KANOLA (Brassica campestris $x$ Brassica napus)
}

\author{
Wenny Mamilianti \\ Staf Pengajar Fakultas Pertanian Universitas Yudharta Pasuruan
}

\begin{abstract}
Abstraksi : Penelitian ini bertujuan untuk mengetahui pengaruh pertumbuhan dan hasil tanaman kanola akibat jarak tanam dan pemberian dosis pupuk kandang yang berbeda. Penelitian dilaksanakan di Kebun Bunga milik CV. Mustika Bunga Mas, desa Karangploko Kecamatan Junrejo kota Batu Jawa Timur. Penelitian menggunakan Rancangan Acak Kelompok (RAK) faktorial dengan dua faktor yaitu : pemberian dosis pupuk kandang (K) dengan 4 level yaitu : K1 dosis Pupuk Kandang 5 ton/ ha ; K2 dosis pupuk kandang 10 ton/ha; K3 dosis pupuk pandang 15 ton/ha; K4 dosis pupuk kandang 20 ton/ha dan faktor kedua jarak tanam (J) dengan 3 level yaitu : J1 jarak tanam 20 X 15 cm; J2 jarak tanam 20 X 20 cm; J3 jarak tanam 20 X 25 cm. Dari hasil analisis regresi bobot biji didapat bahwa pada jarak tanam $20 \times 15 \mathrm{~cm}$ dosis pupuk kandang sampai 20 ton/ha masih menunjukkan peningkatan bobot biji dimana bobot biji tertinggi sebesar 1148,32 kg/ha pada perlakuan K2J2. sedangkan jarak tanam 20 x $20 \mathrm{~cm}$ dosis optimum pupuk kandang adalah 11,68 ton/ha. Dari hasil penelitian bila kondisi iklim lingkungan sesuai dengan lahan penelitian disarankan menggunakan kombinasi perlakuan dosis pupuk kandang 20 ton/ha dengan jarak tanam 20 x $25 \mathrm{~cm}$ karena lebih murah dan efisien dalam pemeliharaan.
\end{abstract}

Kata Kunci : jarak tanam, dosis pupuk kandang

Kanola merupakan tanaman semusim yang merupakan hasil silang antara tanaman Brassica campestris dengan Brassica napus, yang merupakan satu keluarga dengan kobis, sawi, petsai dan lain-lain.

Beberapa keuntungan dari biji kanola antara lain kandungan dari biji kanola lebih tinggi (15-20 \% ) dari biji tanaman lain yang sudah dikenal table 2, selain itu harga minyak kanola relatif sama dengan minyak kedelai, minyak kapas ataupun minyak bunga matahari dan ampas biji kanola sangat baik digunakan sebagai bahan pakan ternak dengan harga sama dengan ampas kedelai. Keuntungan lain dari biji kanola ini adalah budidayanya lebih mudah dan sederhana terutama umur tanaman relatif pendek.

Salah satu alternatif untuk meningkatkan hasil tanaman persatuan luas adalah meningkatkan populasi tanaman hingga batas optimum yaitu dengan jalan pengaturan jarak tanam, dimana tindakan ini merupakan salah satu teknik budidaya yang dapat digunakan untuk meningkatkan produksi. Sitompul dan Guritno (1995) menyatakan bahwa pengaturan tanaman di lapangan juga merupakan salah satu faktor yang menentukan keragaman pertumbuhan tanaman.

Selain pengaturan jarak tanam, peningkatan pproduksi persatuan luas juga dipengaruhi oleh ketersediaan unsur hara dalam tanah diserap dalam rangka penyediaan nutrisi oleh tanaman. Salah satu penyediaan unsur hara dalam tanah adalah dengan cara pemupukan. Pemberian pupuk bisa digunakan pupuk organik dan anorganik. Pemupukan organik lebih efektif dalam meningkatkan kesuburan tanah, selain itu penyediaan unsur hara dapat terpenuhi karena pupuk organik juga mengandung unsur-unsur makro dan 
mikro, misalnya : unsur N,P,K,Ca dan lain-lain. Pupuk organik yang sering dipakai antara lain pupuk kandang, kompos, azolla dan lain-lain. Pupuk kandang merupakan pupuk organik yang dapat memberikan tambahan hara tanah, mempengaruhi sifat fisik dan biologi tanah serta mengembalikan hara yang terangkut hasil panen.

Penelitian ini bertujuan untuk mengetahui pengaruh pertumbuhan dan hasil tanaman kanola akibat jarak tanam dan pemberian dosis pupuk kandang yang berbeda. Sedangkan hipotesis yang dokemukakan adalah diduga terjadi interaksi anatar pemebrian pupuk kandang denngan jarak tanam yang berbeda terhadap pertumbuhan dan hasil tanaman kanola.

\section{METODE}

Penelitian menggunakan Rancangan Acak Kelompok (RAK) faktorial dengan dua faktor yaitu pemberian dosis pupuk kandang $(\mathrm{K})$ dengan 4 level yaitu, K1 = Dosis Pupuk Kandang 5 ton/ ha, K2 = Dosis Pupuk Kandang 10 ton/ha, K3 = Dosis pupuk Kandang 15 ton/ha, K4 : Dosis Pupuk Kandang 20 ton/ha dan faktor kedua jarak tanam (J) dengan 3 level yaitu,: J1 =Jarak Tanam 20 X 15 cm, J2 = Jarak Tanam 20 X $20 \mathrm{~cm}, \mathrm{J3}$ : Jarak Tanam 20 X $25 \mathrm{~cm}$

Masing-masing perlakuan diulang sebanyak 3 kali, sehingga didapat kombinasi perlakuan sebanyak 36 perlakuan. Parameter yang diamati meliputi Pengamatan destruktif meliputi, luas daun dan berat kering tanaman. Pengamatan non destruktif meliputi, tinggi tanaman, jumlah cabang, jumlah polong, jumlah daun dan saat muncul bunga. Sedangkan pengamatan panen meliputi, berat 1000 biji dan produksi per hektar. Data hasil pengamatan dianalisa dengan analisa sidik ragam dengan uji $\mathrm{F}$ kemudian dilanjutkan uji berganda Duncan pada taraf $5 \%$ dan jika terjadi interaksi dilanjutkan dengan analisa regresi.

\section{HASIL DAN PEMBAHASAN \\ Tinggi Tanaman}

Jarak tanam pada umur 80 hst berpengaruh nyata terhadap tinggi tanaman . Hal ini karena pada jarak tanam yang rapat ( $20 \times 15 \mathrm{~cm}$ ) persaingan antar tanaman semakin meningkat terutama dalam hal penggunaan cahaya, dimana tanaman saling menaungi sehingga menyebabkan etiolasi akibat distribusi auksin yang tidak merata hal ini sependapat dengan Harjadi (1993) bahwa pada intensitas cahaya yang rendah tidak terjadi pengaliran auksin ke bagian tanaman yang lain yang tidak terkena cahaya sehingga auksin akan menumpuk dan mendorong tingginya tanaman.

Tabel 1. Rata-rata Tinggi Tanaman (cm) Pada Berbagai Umur Pengamatan (hst) Kerena Pengaruh Jarak Tanam dan Pengaruh Dosis Pupuk Kandang

\begin{tabular}{|c|c|c|c|c|}
\hline \multirow{2}{*}{ Perlakuan } & \multicolumn{4}{|c|}{ Rata-rata tinggi tanaman(cm) } \\
\hline & 20 & 40 & 60 & 80 \\
\hline Jarak Tanam (cm) & & & & \\
\hline 20 X 15 (J1) & 19.19 & 60.10 & 83.08 & $127.812 \mathrm{~b}$ \\
\hline $20 \times 20(\mathrm{~J} 2)$ & 19.60 & 63.79 & 84.63 & $126.481 \mathrm{ab}$ \\
\hline $20 \times 25(\mathrm{~J} 3)$ & 19.22 & 62.00 & 90.21 & $124.334 \mathrm{a}$ \\
\hline Uji DMRT $5 \%$ & tn & tn & tn & \\
\hline $10 \quad(\mathrm{~K} 2)$ & 19.79 & 54.75 a & $85.50 \mathrm{ab}$ & 121.89 \\
\hline
\end{tabular}




\begin{tabular}{|c|c|c|c|c|}
\hline $5 \quad$ (K1) & 18.86 & $53.33 \mathrm{a}$ & $77.75 \mathrm{a}$ & 114.22 \\
\hline 15 (K3) & 19.22 & $73.14 \mathrm{~b}$ & $92.08 \mathrm{~b}$ & 116.83 \\
\hline 20 (K4) & 19.47 & $66.64 \mathrm{~b}$ & $88.56 \mathrm{~b}$ & 121.22 \\
\hline Uji DMRT $5 \%$ & tn & & & tn \\
\hline
\end{tabular}

Keterangan : Huruf berbeda pada kolom yang sama menunjukkan berbeda nyata pada DMRT $5 \%$ Hst : hari satelah tanam tn : tidak nyata

Pada perlakuan pupuk kandang berpengaruh nyata pada umur 40 hst dan 60 hst. Hal ini menunjukkan bahwa dengan peningkatan dosis pupuk kandang meningkatkan pertumbuhan tanaman kanola seperti tinggi tanaman. Hal ini terjadi karena dengan peningkatan pupuk kandang berarti ketersediaan unsur hara yang dimanfaatkan oleh tanaman lebih banyak, hal ini sesuai dengan kondisi pertumbuhan tanaman kanola yang menghendaki tanah subur dan gembur banyak menngandung humus, sehingga tanaman dapat memanfaatkan unsur hara dalam tanah untuk organ vegetatifnya.

\section{Jumlah Daun}

Tabel 2. Rata-rata Jumlah Daun Pada Berbagai Umur Pengamatan (hst) karena pengaruh Jarak Tanam Dan Dosis Pupuk Kandang.

\begin{tabular}{|c|c|c|c|c|}
\hline \multirow{2}{*}{ Perlakuan } & \multicolumn{4}{|c|}{ Rata-rata tinggi tanaman $(\mathrm{cm})$} \\
\hline & 20 & 40 & 60 & 80 \\
\hline \multicolumn{5}{|l|}{ Jarak Tanam $(\mathrm{cm})$} \\
\hline $20 \times 15$ (J1) & 4.25 & 23.21 & 42.40 & 65.29 \\
\hline $20 \times 20(\mathrm{~J} 2)$ & 4.27 & 22.94 & 46.90 & 64.79 \\
\hline $20 \times 25(\mathrm{~J} 3)$ & 4.52 & 22.15 & 45.80 & 66.88 \\
\hline Uji DMRT $5 \%$ & tn & tn & tn & tn \\
\hline \multicolumn{5}{|c|}{ Dosis PK ( ton/ha ) } \\
\hline $5 \quad(\mathrm{~K} 1)$ & 4.28 & 20.86 & 38.17 a & 57.61 a \\
\hline $10 \quad(\mathrm{~K} 2)$ & 4.31 & 22.42 & $42.33 \mathrm{ab}$ & $63.67 \mathrm{~b}$ \\
\hline 15 (K3) & 4.33 & 24.94 & $49.81 \mathrm{~b}$ & $70.97 \mathrm{c}$ \\
\hline 20 (K4) & 4.47 & 22.83 & $49.81 \mathrm{~b}$ & $70.36 \mathrm{c}$ \\
\hline Uji DMRT 5 \% & tn & tn & & \\
\hline
\end{tabular}

Keterangan : Huruf berbeda pada kolom yang sama menunjukkan berbeda nyata pada DMRT $5 \%$ Hst : hari satelah tanam tn : tidak nyata

Perlakuan pupuk kandang menunjukkan perbedaan nyata terhadap jumlah daun pada umur 60 dan 80 hst, tetapi tidak menunjukkan perbedaan nyata pada umur 20 dan 40 hst. Hal ini disebabkan dosis pupuk kandang dapat memperbaiki struktur tanah sehingga memudahkan perkembangan akar yang sekaligus meningkatkan daya penetrasi dan absorbsi hara dari dalam tanah oleh akar. Selain itu peningkatan dosis pupuk kandang menyebabkan tanah banyak tersedia unsur hara yang dapat dimanfaatkan tanaman untuk membentuk organ-organ tanaman khususnya jumlah daun.

\section{Jumlah Cabang}

Jarak tanam berpengaruh terhadap jumlah cabang, dimana jarak tanam yang lebar menyebabkan jumlah cabang lebih banyak dibanding jarak tanam rapat, hal ini disebabkan karena pada jarak tanam renggang tersedia ruang untuk perkembangan 
jumlah cabang dan persaingan antar tanaman rendah sehingga memungkinkan tanaman tumbuh tanpa hambatan.

Pada Tabel 3. perlakuan dosis pupuk kandang menunjukkan perbedaan nyata pada umur 80 hst. Pada dosis 10 ton/ha dan 15 ton/ha menghasilkan jumlah cabang terbanyak tetapi tidak berbeda nyata dengan dosis 20 ton/ha. Pupuk kandang merupakan salah satu pupuk organik yang dapat mencegah kehilangan air tanah dan laju infiltrasi air. Dengan terikatnya air oleh humus berarti dapat mengurangi air perkolasi sehingga pencucian unsur hara dapat berkurang. Hal ini dapat mengurangi pencucian hara akibat air perkolasi, sehingga unsur hara tersedia selama pertumbuhan tanaman salah satunya pembentukan cabang.

Tabel 3. Rata-rata Jumlah Cabang Pada Berbagai Umur Pengnamatan (hst) karena pengaruh Jarak Tanam Dan Dosis Pupuk Kandang.

\begin{tabular}{|l|l|l|l|}
\hline \multirow{2}{*}{ Perlakuan } & \multicolumn{3}{c|}{ Rata-rata tinggi tanaman $(\mathrm{cm})$} \\
\cline { 2 - 4 } & \multicolumn{2}{c|}{40} & \multicolumn{2}{c|}{80} \\
\hline Jarak Tanam (cm) & & & \\
\hline 20 X 15(J1) & 4.00 & $11.02 \mathrm{a}$ & $20.25 \mathrm{a}$ \\
\hline 20 X 20 (J2) & 4.13 & $11.98 \mathrm{~b}$ & $20.79 \mathrm{ab}$ \\
\hline 20 X 25(J3) & 4.13 & $12.25 \mathrm{~b}$ & $21.60 \mathrm{~b}$ \\
\hline Uji DMRT 5 \% & tn & & \\
\hline Dosis PK ( ton/ha ) & & & \\
$5 \quad$ (K1) & 4.08 & 11.78 & $19.56 \mathrm{a}$ \\
$10 \quad$ (K2) & 4.22 & 11.89 & $21.36 \mathrm{~b}$ \\
15 (K3) & 4.03 & 11.33 & $21.36 \mathrm{~b}$ \\
20 (K4) & 4.00 & 12.00 & $21.25 \mathrm{~b}$ \\
Uji DMRT 5 \% & tn & tn & \\
\hline
\end{tabular}

Keterangan : Huruf berbeda pada kolom yang sama menunjukkan berbeda nyata pada DMRT $5 \%$ Hst : hari satelah tanam tn : tidak nyata

\section{Luas Daun}

Tebel 4. Rata-rata Luas Daun (cm ) Pada umur 40, 60, dan 80 hst Karena Pengaruh Interaksi Antara Jarak Tanam dan Dosis Pupuk Kandang

\begin{tabular}{|c|c|c|c|}
\hline \multirow{2}{*}{ Perlakuan } & \multicolumn{3}{|c|}{ Rata-Rata Luas daun $(\mathrm{cm})$} \\
\hline & 40 & 60 & 80 \\
\hline KIJI & 900.79 ab & $2967.50 \quad a b$ & $3217.58 \mathrm{ab}$ \\
\hline KIJ2 & 858.84 a & 2840.76 a & 3105.91a \\
\hline KIJ3 & 1054.10 abc & $2909.21 \quad \mathrm{a}$ & 3568.72ab \\
\hline K2JI & 968.84 abc & 2674.29 a & 3143.63ab \\
\hline K2J2 & 1128.13 с & $3724.80 \quad \mathrm{c}$ & 4589.48c \\
\hline K2J3 & 952.39 abc & 3511.58 ab & 3777.59ab \\
\hline K3JI & 943.59 abc & $3087.21 \mathrm{ab}$ & 3820.98ab \\
\hline K3J2 & 1098.88 bc & $3096.40 \mathrm{ab}$ & 3704.88ab \\
\hline K3J3 & 987.29 abc & 3119.70 ab & 3604.21ab \\
\hline K4JI & 1080.02 bc & 2970.68 ab & 3347.83ab \\
\hline K4J2 & 984.47 abc & $3189.10 \quad a b$ & 3732.26ab \\
\hline K4J3 & 956.92 abc & $3145.30 \quad a b$ & $3959.08 \mathrm{bc}$ \\
\hline
\end{tabular}

Keterangan : Angka-angka yang didampingi huruf yang sama menunjukkan tidak berbeda nyata pada DMRT 5 \% Hst : hari setelah tanam 
Pengamatan luas daun terdapat interaksi nyata antara jarak tanam dan dosis pupuk kandang, dimana jarak tanam 20 × $20 \mathrm{~cm}$ pada dosis 10 ton/ha menghasilkan luas daun lebih tinggi Unsur hara yang tersedia dalam tanah dengan penambahan dosis pupuk kandang dapat mencukupi sejumlah populasi tanaman (250.000) tersebut, terutama dalam sintesa bahan organik dalam proses fotosintesis yang membutuhkan unsur hara. Hasil fotosintesa berupa karbohidrat yang ditranslokasikan ke bagian organ tanaman termasuk ke bagian daun dapat tumbuh dan berkembang karena ruang tumbuh yang cukup tidak saling menaungi antar tajuk tanaman, sesuai dengan penelitian Mimbar (1990) dalam Nurjanah (1993) bahwa semakin rapat jarak tanam akan diperoleh luas daun yang semakin berkurang akibat saling menaungi tajuk tanaman.

\section{Berat Kering Tanaman}

Tabel 5. Rata-Rata Berat Kering (g) Pada Berbagai Umur Pengamatan (hst) Karena Pengaruh Jarak Tanam Dan Dosis Pupuk Kandang.

\begin{tabular}{|c|c|c|c|c|}
\hline \multirow[t]{2}{*}{ Perlakuan } & \multicolumn{4}{|c|}{ Rata-rata berat kering (g) } \\
\hline & 20 & & 40 & 80 \\
\hline \multicolumn{5}{|l|}{ Jarak Tanam (cm) } \\
\hline $20 \times 15 \mathrm{~cm}(\mathrm{~J} 1)$ & 2.90 & 8.60 & $\mathrm{a}$ & 87.06 \\
\hline $20 \times 20 \mathrm{~cm}(\mathrm{~J} 2)$ & 3.07 & 10.10 & $a b$ & 88.97 \\
\hline $20 \times 25 \mathrm{~cm}(\mathrm{~J} 3)$ & 2.94 & 10.99 & b & 91.81 \\
\hline Uji DMRT 5 \% & tn & & & tn \\
\hline \multicolumn{5}{|l|}{ Dosis PK (ton/ha) } \\
\hline $5 \quad(\mathrm{~K} 1)$ & 2.86 & 7.88 & $\mathrm{a}$ & $81.96 \mathrm{a}$ \\
\hline $10 \quad(\mathrm{~K} 2)$ & 2.90 & 9.40 & $\mathrm{ab}$ & $88.86 \mathrm{ab}$ \\
\hline 15 (K3) & 3.05 & 10.25 & bc & $93.89 \mathrm{~b}$ \\
\hline $20 \quad(\mathrm{~K} 4)$ & 3.08 & 12.07 & c & $92.41 \mathrm{~b}$ \\
\hline Uji DMRT 5\% & tn & & & \\
\hline
\end{tabular}

Keterangan : Huruf berbeda pada kolom yang sama menunjukkan berbeda nyata pada DMRT 5 \%. Hst : hari setelah tanam.

Berat kering tanaman dipengaruhi jarak tanam pada umur pengamatan 40 hst, dengan jarak tanam yang semakin rapat persaingan untuk mendapatkan faktor tumbuh semakin ketat terutama kegiatan fotosintesi yang menurun akibat persaingan cahaya dan suhu sebagai bahan fotosintesis terhadap daun yang saling menaungi.

Penurunan hasil fotosintesis tersebut dapat menghambat pertumbuhan organorgan tanaman yang mempengaruhi berat kering tanaman. Jarak tanam renggang mengakibatkan persaingan antar tanaman relatif rendah sehingga hasil fotosintesis tinggi untuk pembentukan organ-organ tanaman, sehingga mempengaruhi berat kering tanaman.

Perlakuan pupuk kandang juga mempengaruhi berat kering tanaman, dimana pada peningkatan dosis pupuk kandang dengan 15 ton/ha dan 20 ton/ha menunjukkan berat kering tertinggi. Hal ini berhubungan dengan luas daun yang optimal dan penambahan jumlah daun, dimana semakin luas permukaan daun maka fotosintat yang dihasilkan akan meningkat, sehingga mempengaruhi bahan kering tanaman seperti yang dikemukakan oleh Jumin (1991) bahwa peningkatan total bahan kering tanaman dapat dicapai dengan mengoptimalkan luas daun. Ketersediaan unsur hara dari pemberian pupuk kandang sebagai salah satu bahan fotosintesis mengakibatkan proses fotosintesis berjalan lancar sehingga hasil fotosintesi (fotosintat) berupa karbohidrad sebagai bahan energi untuk 
pertumbuhan tanaman di akumulasikan ke dalam organ-organ tanaman. Hasil akumulasi karbohidrat tersebut dapat mempengaruhi berat kering tanaman.

\section{Saat Muncul Bunga}

Table 6. Rata-Rata Muncul Bunga (Hst) Karena Pengaruh Perlakuan Jarak Tanam Dan Dosis Pupuk Kandang.

\begin{tabular}{|l|l|}
\hline Perlakuan & Rata-Rata saat muncul bunga (hst) \\
\hline Jarak Tanam (cm) & \\
20 x 15 (J1) & 46.83 \\
20 x 20 (J2) & 46.00 \\
20 x 25 (J3) & 46.33 \\
Uji DMRT 5 \% & tn \\
\hline Dosis PK (ton/ha) & \\
5 & 46.33 \\
10 & 46.33 \\
15 & 46.11 \\
20 & 46.78 \\
Uji DMRT 5 \% & tn \\
\hline
\end{tabular}

Keterangan : hst: hari setelah tanam. tn : tidak nyata

Jarak tanam maupun dosis pupuk kandang tidak mempengaruhi saat muncul bunga. Pembungaan tanaman kanola lebih banyak dipengaruhi oleh keadaan lingkungan terutama kelembaban, suhu dan iklim. Saat pembungaan lebih dipengaruhi oleh suhu yang tinggi. Adanya suhu yang rendah dan penyinaraan yang sedikit pada saat penelitian ini akibat pergantian musim hujan dan musim kemarau yang tidak menentu mengakibatkan perlakuan jarak tanam dan dosis pupuk kandang tidak terlihat pengaruhnya terhadap saat muncul bunga. Meskipun tersedia unsur hara dan ruang yang cukup bagi tanaman, tetapi lingkungan terutama suhu yang kurang mendukung menyebabkan tidak adanya perbedaan saat pembungaan pada semua perlakuan.

\section{Jumlah Polong}

Tabel 7 Menunjukkan bahwa dosis pupuk kandang 10 ton/ha menghasilkan jumlah polong terbanyak tetapi tidak berbeda dengan dosis 15 dan 20 ton/ha pada umur 60 hst, sedangkan pada umur 80 hst dosis pupuk kandang 10 ton/ha menunjukkan jumlah polong terbanyak tetapi tidak berbeda nyata dengan dosis 15 ton/ha sedangkan dosis terendah terjadi pada dosis 5 ton/ha.

Tabel 7. Rata-rata jumlah polong pada berbagai umur pengamatan (hst) karena pengaruh jarak tanam dan dosis pupuk kandang

\begin{tabular}{|llll|}
\hline \multicolumn{1}{|c}{ Perlakuan } & \multicolumn{3}{c|}{ Rata-rata jumlah polong } \\
\cline { 2 - 4 } & \multicolumn{2}{c|}{60} & 80 \\
\hline Jarak tanam (cm) & & 165.42 & 323.75 \\
20 x15 (J1) & 14.60 & 165.83 & 323.50 \\
20 x20 (J2) & 15.17 & 165.79 & 324.96 \\
20 x 25 (J3) & 15.29 & tn & tn \\
Uji DMRT 5 \% & tn & &
\end{tabular}




\begin{tabular}{|lllll|}
5 & (K1) & 14.25 & $160.67 \mathrm{a}$ & $318.44 \mathrm{a}$ \\
10 & (K2) & 14.56 & $170.22 \mathrm{~b}$ & $329.06 \mathrm{c}$ \\
15 & (K3) & 15.53 & $166.78 \mathrm{~b}$ & $328.17 \mathrm{bc}$ \\
20 (K4) & 15.75 & $165.06 \mathrm{ab}$ & $320.61 \mathrm{ab}$ \\
Uji DMRT 5 \% & th & & \\
\hline
\end{tabular}

Keterangan : Huruf berbeda pada kolom yang sama menunjukkan berbeda nyata pada DMRT 5 \% Hst : hari setelah tanam. tn : tidak nyata

\section{Berat 1000 biji}

Tabel 8. Rata-Rata Berat 1000 Biji (G) Karena Pengaruh Perlakuanjarak Tanam Dosis Dosis Pupuk Kandang

\begin{tabular}{|ll|}
\hline Perlakuan & Rata-rata berat 1000 biji $(\mathrm{g})$ \\
\hline Jarak tanam $(\mathrm{cm})$ & \\
$20 \times 15(\mathrm{~J} 1)$ & 2.99 \\
$20 \times 20(\mathrm{~J} 2)$ & 3.09 \\
$20 \times 25$ (J3) & 3.09 \\
Uji DMRT $5 \%$ & tn \\
\hline Dosis PK (ton/ha) & \\
$5 \quad$ K1) & 2.93 \\
$10 \quad$ K2) & 3.04 \\
$15 \quad$ K3) & 3.15 \\
$20 \quad($ K4) & 3.10 \\
Uji DMRT $5 \%$ & tn \\
\hline
\end{tabular}

Keterangan: tn : tidak nyata pada uji dmrt $5 \%$

Perlakuan jarak tanam maupun perlakuan pemberian dosis pupuk kandang juga tidak berbeda nyata pada berat 1000 biji (table 8). Tabel 8 menunjukkan bahwa semua perlakuan jarak tanam dan pemberian dosis pupuk kandang yang berbeda serta kombinasi antar perlakuan tidak menunjukkan perbedaan nyata.

\section{Produksi}

Tabel 9. Rata-Rata Produksi (Kg/Ha) Karena Pengaruh Interaksi Antara Jarak Tanam Dan Dosis Pupuk Kandang

\begin{tabular}{|l|c|l|l|l|}
\hline Perlakuan & \multicolumn{5}{|c|}{ Rata-rata bobot biji (kg/ha) } \\
\hline Jarak Tanam $(\mathrm{cm})$ & $5(\mathrm{~K} 1)$ & \multicolumn{1}{|c|}{$10(\mathrm{~K} 2)$} & $15(\mathrm{~K} 3)$ & \multicolumn{1}{|c|}{ (K4) } \\
\hline $20 \times 15(\mathrm{~J} 1)$ & $973.45 \mathrm{ab}$ & $911.77 \quad \mathrm{a}$ & 1008.06 abcd & $1015.84 \mathrm{abcd}$ \\
\hline $20 \times 20(\mathrm{~J} 2)$ & $941.19 \mathrm{a}$ & $1148.33 \mathrm{~d}$ & $1111.55 \mathrm{bcd}$ & 958.04 a \\
\hline $20 \times 25(\mathrm{~J} 3)$ & $992.95 \mathrm{abc}$ & $1140.56 \mathrm{~cd}$ & $986.15 \mathrm{ab}$ & 1010.59 abcd \\
\hline Uji DMRT 5\% & & & & \\
\hline
\end{tabular}

Ketrengan : Angka-angka yang didampingi huruf yang sama menunjukkan tidak berbeda nyata pada DMRT $5 \%$

Tabel 9. diketahui bahwa kombinasi jarak tanam 20 x $20 \mathrm{~cm}$ pada dosis 10 ton/ha menunjukkan produksi tertinggi, sedangkan produksi yang paling rendah pada kombinasi perlakuan jarak tanam $20 \times 15 \mathrm{~cm}$ dengan dosis 5 ton/ha.

Parameter hasil yang diamati meliputi jumlah polong, berat 1000 biji dan bobot biji/ha. Pengamatan jumlah polong dipengaruhi oleh dosis pupuk kandang, dimana pada dosis 10 ton/ha menghasilkan jumlah polong lebih banyak tetapi tidak berbeda nyata pada dosis 15 ton/ha. Pupuk kandang dapat mensuplai unsur hara makro seperti : 
$\mathrm{N}, \mathrm{P}, \mathrm{K}, \mathrm{Ca}, \mathrm{Na}, \mathrm{Cl}$ dan unsur hara mikro meskipun dalam jumlah relatif sedikit selain dapat memperbaiki struktur tanah sehingga memudahkan tanaman dalam pengambilan hara di dalam tanah. Tersedianya hara dimanfaatkan oleh tanaman untuk pertumbuhan vegetatif yang mempengaruhi pembentukan polong. Polong terbentuk pada batang dan cabang yang ada sehingga pertumbuhan vegetatif yang baik dapat mempengaruhi jumlah polong.

Jarak tanam maupun dosis pupuk kandang yang diberikan belum menampakkan pengaruh terhadap berat 1000 biji, hal ini dapat diterangkan bahwa asimilat yang dihasilkan oleh tanaman dan digunakan untuk pembentukan biji cukup seimbang untuk setiap perlakuan jarak tanam yang digunakan. Dimana pada jarak tanam yang rapat terjadi pengurangan jumlah polong yang dihasilkan sedangkan banyaknya asimilat yang diakumulasikan kedalam biji tetap, sebaliknya pada jarak tanam renggang dengan jumlah polong yang banyak asimilat harus diakumulasikan kedalam biji yang jumlahnya lebih banak, sehingga tidak ada perbedaan berat 1000 biji akibat perlakuan jarak tanam. Peningkatan dosis pupuk kandang juga belum menunjukkan perbedaan nyata terhadap berat 1000 biji, hal ini dapat dijelaskan bahwa dengan jumlah pupuk kandanh yang didalamnya mengandung unsure N,P,K yang semakin tinggi belum bisa mempengaruhi berat 1000 biji karena energi yang dihasilkan tanaman dengan memanfaatkan unsur hara yang didukung dengan lingkungan yang sesuai ditranslokasikan secara seimbang untuk pembentukan organ generatif terutama pembentukan biji.

Pada pengamatan produksi terdapat interaksi antara jarak tanam dan dosis pupuk kandang, pada jarak tanam $20 \times 20 \mathrm{~cm}$ dengan dosis 10 ton/ha menghasilkan produksi lebih tinggi dibanding perlakuan yang lain. Produksi tanaman kanola dapat mencapai hasil yang tinggi secara terus-menerus. Selain itu produksi yang tinggi dapat dicapai bila faktor tumbuh seperti tanah yang subur, lingkungan yang sesuai dengan pertumbuhan dan cara budidaya sebagai satu kesatuan yang salah satunya tidak dalam keadaan kekurangan. Dari pemenuhan faktor tumbuh diatas maka proses fotosintesis dapat dicapai secara maksimal, hal ini sangat mempengaruhi produksi tanaman kanola.

Hasil produksi suatu tanaman mempunyai hubungan yang tidak dapat dipisahkan dengan kerapatan tanaman, karena itu penentuan jarak tanam sangat menentukan jumlah produksi yang dihasilkan.

Unsur hara dalam jumlah unsur hara dalam jumlah cukup tersedia dalam tanah sangat penting bagi tanaman sebagai bahan fotosintesis dan energi untuk pertumbuhan vegetatif maupun generatif. Oleh karena itu penggabungan antara jarak tanam yang optimum dengan jumlah unsur hara yang mencukupi dapat meningkatkan produksi yang dihasilkan. Dengan jumlah unsur hara yang terdapat dalam tanah dapat memenuhi kebutuhan sejumlah tanaman disalah satu luasan tertentu, sehingga pertumbuhan vegetatif dan generatif cukup tersedia energi khususnya pembentukan dan pengisian biji yang menentukan bobot biji /ha nya

Dari hasil analisis regresi produksi untuk jarak tanam 20 x $15 \mathrm{~cm}$ sampai dosis 20 $\mathrm{kg} / \mathrm{ha}$ pupuk kandang masih menunjukkan peningkatan hasil dengan mengikuti garis linier. Jarak tanam 20 × $20 \mathrm{~cm}$ dosis optimum pupuk kandang adalah 12,54 ton/ha, sedangkan pada jarak tanam 20 × 25 cm dosis optimum pupuk kandang adalah 11,68 ton/ ha. 


\section{KESIMPULAN DAN SARAN}

Perlakuan jarak tanam berpengaruh nyata terhadap tinggi tanaman 80 hst, jumlah cabang umur 60 hst dan 80 hst dan berat kering umur 40 hst.Perlakuan pemberian dosis pupuk kandang berpengaruh nyata terhadap tinggi tanaman umur 40 dan 60 hst, jumlah cabang umur 80 hst, berat kering 40 dan 80 hst jumlah polong umur 60 dan 80 hst.Jarak tanam 20 x $15 \mathrm{~cm}$ sampai dosis 20 ton/ha menunjukkan peningkatan produksi per hektarnya. Jarak tanam 20 x $20 \mathrm{~cm}$ dosis optimum pupuk kandang adalah 12,54 ton/ha dan pada jarak tanam 20 x 25 cm dosis optimum pupuk kandang adalah 11,68 ton/ha.

Dari hasil penelitian bila kondisi iklim lingkungan sesuai dengan lahan penelitian disarankan menggunakan kombinasi perlakuan dosis pupuk kandang 20 ton/ha dengan jarak tanam 20 x $25 \mathrm{~cm}$ karena lebih murah dan efisien dalam pemeliharaan. Selain itu perlu percobaan/ uji lanjutan tentang beberapa perlakuan iklim dan lingkungan yang berbeda untuk mengetahui lebih lanjut hasil dan pertumbuhan tanaman kanola khususnya dari segi adaptasinya.

\section{DAFTAR PUSTAKA}

Anonymous (a), 1998. Growth Stages Of The Canola Plant. http : www. Canola Council Organisation. Com

(b), 1998. The basis Of Canola Yields. http: www. Canola Council Organisation. Com.

( c), 1998. Canola Production. Ohio Agronomy Guide. Bul : 472.

Berglund, DR and Mckay Kent. 1998. Canola Production. North Dakota State University (NDSU) Extension Service.

Christmas, E.P. and Stephen, S.H. 1992. Winter Canola - An Alternative Crop In Indiana. Purdue University Coorperative Extension Service west Lafayette, Indiana.

Donald, C.M. 1968, Competition Among Crop And Pasture Plant. Adv. Agronomy. Acad. NY. London. P : 15-84.

Dwijosepoetro, 1988. Pengaruh Kepadatan Tanaman Terhadap Pertumbuhan Dan hasil 2 Varietas Kacang Hijau (Phaseolus radiatus L). Tesis S1 Jurusan Budidaya Pertanian Pertanian Fakultas Pertanian. Unibraw. Malang

Hakim, N. Y.M. Nyakpak, A.M. Lubis, S.G Nugroho, M.A Diha, G.B. Hong, H.H Barlay, 1986. Dasar-Dasar Ilmu Tanah. Universitas Lapang. P. 320.

Harjadi, S.S. 1993. Pengantar Agronomi. Departement Agronomi Fakultas Pertanian. IPB. P. 185

Jumin, H.B. 1991. Dasar- Dasar Agronomi. Rajawali Pers. Jakarta p. 140. 
. 1992. Ekologi Tanaman. Rajawali Pers. Jakarta. P. 162.

Mimbar,S.M. 1990. Pengaruh Jarak Tanam, Jumlah Tanaman/ rumpun, Kerapatan Populasi Terhadap Pertumbuhan Dan Hasil Kacang Hijau Merak. Agrivita 13 (1):p. 26-29.

Muhammad, H, Wanti D dan Lukman H. 1992. Pengaruh Takaran Pupuk Kandang dan Kombinasi Pupuk N,P,K terhadap Produksi Petsai (Brassica Pekinensis Rupr). J. Hort. 2 (3) : 1-5.

Nasution, M.A. 1998. Pengaruh Pemberian Pupuk Kandang dan kalium Terhadap Produksi dan Kualitas Jagung Manis ( Zea mays saccharata) Pada Lahan Kering. Skripsi S-1 Jurusan Budidaya Pertanian. Fakultas Pertanian. Unibraw. Malang.

Nurjanah, I. 1994. Pengaruh Jarak Tanam Antar Barisan Terhadap Pertumbuhan Dan Hasil Dua Varietas Wijen ( Sesamum indicum ). Skripsi Jurusan Budidaya Pertanian. Fakultas Pertanian. Unibraw. Malang.

Purwati, 1986. Budidaya Tanaman Petsai Di Dataran Tinggi. Pustaka Jaya. Jakarta.

Sarief. E.S. 1986. Kesuburan dan Pemupukan Tanah Pertanian. C.V. Pustaka Buana. Bandung.P.182.

Sitompul, S.M. dan Bambang G. 1995. ANalisis Pertumbuhan tanaman. Gadjah Mada University Press. Yogyakarta. P.412.

Suriawiria, U (a). 1998. Kanola, bahan Baku Minyak Nabati Untuk Minyak Goreng, Kosmetik dan minyak Bakar. Makalah Bioteknologi dan Agroindustri. ITB. Bandung.p.1-4. 
